\title{
Sytuacja prawna młodych rolników w procesie zmiany generacji w rolnictwie
}

1. Profesor Andrzej Stelmachowski w swoim opracowaniu pt. „Problemy ludzi starych na wsi w aspekcie prawnym" pisał m.in., że nowoczesności w gospodarstwach rolnych nie da się osiągnąć bez radykalnego odmłodzenia rolnictwa i rozwiązania problemu ludzi starych. ${ }^{2}$ Przedmiotem bezpośredniego zainteresowania i troski Autora była przede wszystkim sytuacja społeczna i materialna starszych rolników. Autor wskazywał na prawne możliwości określenia statusu tej grupy rolników, postulując zwłaszcza objęcie ich systemem ubezpieczeń społecznych, czy wprowadzenia modyfikacji do umów dożywocia. Polegałyby one, zdaniem autora, na przyjęciu państwowych gwarancji udzielanych w związku z umowami dożywocia. Świadczenia dożywotnie dokonywane byłyby przez Państwo, które z kolei w drodze regresu ściągałoby te świadczenia od nabywcy oraz uzyskałoby możliwość wpływania na treść umów dożywocia (np. co do wieku i kwalifikacji nabywcy) $)^{3}$. Lektura wspomnianego opracowania wyraźnie potwierdza, że Autor nierozłącznie rozpatrywał trzy aspekty podjętej problematyki. Postulując objęcie opieką prawną starszych rolników, wskazywał na skutki przyjęcia regulacji ich dotyczących dla przyspieszania procesu przejmowania gospodarstw rolnych przez młodych rolników, co z kolei sprzyjać powinno poprawie efektywności w rolnictwie. Przesłanki gospodarcze były przez autora szczególnie mocno akcentowane i wskazywane jako zasadniczy cel poszukiwania nowych rozwiązań służących poprawie sytuacji materialnej i społecznej starszych rolników. Autor wyraźnie akcentował, że „bez rozwiązania zagadnienia ludzi starych na wsi nie rozwiążemy problemów gospodarczych o pierwszorzędnym znaczeniu"4.

2. Kontynuację rozważań A. Stelmachowskiego na wskazany temat podjął R. Budzinowski, zaznaczając już w tytule swego opracowania, że jego uwagi są

Uniwersytet Łódzki.

A. Stelmachowski, Problemy ludzi starych na wsi w aspekcie prawnym, Nowe Prawo 1972, z. 7-8, s. 1051. Ibidem, s. 1052.

Ibidem, s. 1043 
bezpośrednim nawiązaniem do problematyki podjętej przez A. Stelmachowskiego ${ }^{5}$. Autor wskazywał, że temat dotyczący poszukiwania najlepszych rozwiązań zabezpieczających starość ludności wiejskiej pozostał aktualny także w nowym, zmienionym stanie prawnym. Pomimo obowiązywania już systemu ubezpieczenia społecznego rolników ${ }^{6}$ dającemu rolnikom zabezpieczenie materialne, pozostaje - jak wskazuje Autor - wiele problemów do rozwiązania. W tym miejscu warto odnotować uwagi Autora na temat niektórych rozwiązań ustawy o ubezpieczeniu społecznym rolników z 1990 roku. Z punktu widzenia ochrony interesów starszych rolników Autor ocenia pozytywnie m.in. konstrukcję umowy z następcą (art. 84), która sprzyjać ma harmonijnej zmianie generacji w rolnictwie, czy np. istniejącą możliwość rozwiązania umowy z następcą oraz umowy zawartej w celu wykonania umowy z następcą, a także wcześniej zawartych umów przekazania gospodarstwa rolnego następcy (art. 119 w związku z art. 89 pkt 1 i 3 oraz art. 87). Takie rozwiązania są wynikiem ewolucji i potwierdzają znaczenie przesłanki psychologicznej prawa własności. Rolnik przekazujący gospodarstwo rolne ma czas (w przypadku umowy z następcą) na podjęcie decyzji dotyczącej przekazania własności gospodarstwa rolnego, a w przypadku pogorszenia się relacji: właściciel gospodarstwa-następca rolnik ma prawo wystąpić do sądu o rozwiązanie umowy. Cytowane rozwiązania są, jak wskazuje Autor, korzystne dla rolnika, ale równocześnie mogą budzić wątpliwości z punktu widzenia stabilizowania sytuacji prawnej następcy ${ }^{7}$.

Jak trafnie zauważa R. Budzinowski, problemy ludzi starych rysują się szczególnie wyraźnie na tle zmiany generacji w rolnictwie. Autor wskazuje, że ustawodawca powinien tak kształtować prawne formy umożliwiające zmianę pokoleń, by harmonijnie łączyć interesy starego rolnika $\mathrm{z}$ interesami tego, który gospodarstwo rolne otrzymał ${ }^{8}$. Przyjęte przez autora założenie badawcze skłoniło go, do dokonania analizy wybranej regulacji prawnej z punktu widzenia zwłaszcza sytuacji prawnej starszych rolników. Ta analiza pozwoliła sformułować ocenę, że: „patrząc z prawnego punktu widzenia - problemy ludzi starych na wsi są coraz lepiej rozwiązywane, a ich potrzeby w coraz szerszym zakresie uwzględniane przez ustawodawcę." Aczkolwiek R. Budzinowski sygnalizuje, że proces przekazywania gospodarstw rolnych następcom wymaga przyspieszenia ze względu na przebudowę struktury agrarnej ${ }^{10}$, to jednak ten cel nie wydaje się być tak wyraźnie zaznaczany, jak w cytowanym wcześniej opracowaniu A. Stelmachowskiego.

$5 \quad$ R. Budzinowski, Problemy ludzi starszych na wsi w aspekcie prawnym, RPEiS 1999, z. 1, s. 199 i n.

6 Ustawa z dnia 20.XII.1990 r. O ubezpieczeniu społecznym rolników, Dz.U. z 1998 r. Nr 7, poz. 252 z późn. zm., cyt. dalej jako „ustawa z 1990 r.”

7 R. Budzinowski, Problemy..., op. cit., s. 205.

8 Ibidem, s. 202.

9 Ibidem, s. 211.

10 Ibidem, s. 200. 
W zakresie wskazanego $\mathrm{w}$ tytule niniejszego opracowania jednego $\mathrm{z}$ aspektów zmiany generacji w rolnictwie zderzają się więc w sposób nierozłączny: 1) sytuacja prawna starszych rolników, 2) sytuacja prawna młodych rolników i 3) określenie celu, którego realizacji służyć mają przyjmowane regulacje prawne określające status podmiotów uczestniczących w procesie zmiany generacji w rolnictwie.

3. Jak wynika z art. 39 ust. 1 Traktatu o utworzeniu Wspólnoty Europejskiej ${ }^{11}$, celem wspólnej polityki rolnej jest m.in.: a) zwiększenie wydajności rolnictwa przez popieranie postępu technicznego, racjonalny rozwój produkcji rolnej oraz możliwie najlepsze wykorzystanie czynników produkcji, a w szczególności siły roboczej, oraz b) zapewnienie w ten sposób odpowiedniego poziomu życia społeczności wiejskiej, w szczególności poprzez wzrost indywidualnych dochodów osób zatrudnionych w rolnictwie. Jak wskazała A. Jurcewicz, użycie w cyt. art. 39 pkt b określenia: „w ten sposób” sprawia, że pkt a i b są ze sobą ściśle powiązane ${ }^{12}$. Na tle treści art. 39 TWE autorka zauważa, że zadanie zapewnienia odpowiedniego standardu życiowego producentów rolnych powinno być osiągnięte poprzez zmiany strukturalne rolnictwa ${ }^{13}$. Mając na uwadze ten punkt widzenia, uzasadnione jest podkreślenie, że rozpatrywanie sytuacji młodych rolników w procesie zmiany generacji w rolnictwie musi być nierozłącznie powiązane z celami gospodarczymi i przekształceniami strukturalnymi w rolnictwie. Ten aspekt gospodarczy jest także wyraźnie akcentowany w Układzie Europejskim z dnia 16 grudnia $1991 \mathrm{r}^{14} \mathrm{~W}$ treści art.77 cytowanego Układu czytamy m.in., że współpraca w dziedzinie rolnictwa i sektora rolno-spożywczego będzie miała na celu zwiększenie efektywności rolnictwa i sektora rolno-spożywczego i w szczególności będzie dotyczyć: rozwoju gospodarstw prywatnych (art. 77 ust. 1).

W zakresie oceny realizacji tego zadania należy brać pod uwagę zarówno przesłanki przedmiotowe, jak i podmiotowe, mające znaczenie dla rozwoju gospodarstw rolnych, w tym m.in. także uregulowanie sytuacji prawnej osób podejmujących prowadzenie gospodarstwa rolnego. Grupą osób szczególnie pożądanych dla podejmowania pracy w gospodarstwach rolnych są niewątpliwie młodzi rolnicy. Powstaje więc pytanie, czy przyjmowane regulacje prawne dotyczące tej kategorii podmiotów są w odpowiedni sposób kojarzone z tą częścią regulacji prawnej, która dotyczy przekształceń strukturalnych w rolnictwie. Jak już bowiem wskazano, zagadnienia te są nierozłącznie związane.

11 1997, s.11 in.

12 A. Jurcewicz (w:) Traktat ustanawiający Wspólnotę Europejską. Komentarz, t. I, pod red. A. Wróbla, Warszawa 2008, s. 727.

13 A. Jurcewicz, Wspólna polityka rolna Unii Europejskiej (w:) Prawo rolne, pod red.A.Stelmachowskiego, Warszawa 2009 , s. 75.

14 Układ Europejski ustanawiający stowarzyszenie między Rzecząpospolitą Polską z jednej strony a Wspólnotami Europejskimi i ich państwami członkowskimi z drugiej strony, Dz.U. z 1994 r. Nr 11, poz. 38, (w:) Prawo Wspólnot Europejskich, op. cit., s.145 i n. 
4. Daje temu wyraz także aktualne ustawodawstwo dotyczące przekształceń strukturalnych w rolnictwie. Jak wynika np. z art. 20 rozporządzenia Rady (WE) nr 1698/2005 $5^{15}$, podejmowanie działalności przez młodych rolników znajduje się w grupie środków ukierunkowanych na wsparcie konkurencyjności sektora rolnego i leśnego. Warto zauważyć, że zgodnie z art. 22 cytowanego rozporządzenia wsparcia na podejmowanie działalności przez młodych rolników udziela się osobom, które mają mniej niż 40 lat oraz po raz pierwszy podejmują działalność w gospodarstwie rolnym jako kierujący gospodarstwem. Zaakcentowano więc wyraźnie aspekt demograficzny, który szerzej jest akcentowany w Programie Rozwoju Obszarów Wiejskich na lata 2007-2013 ${ }^{16}$. W części PROW dotyczącego ułatwiania startu młodym rolnikom wskazano m.in., że celem działania jest ,stymulowanie zmian strukturalnych w sektorze rolnym przez ułatwienie przejmowania lub zakładania gospodarstw rolnych przez osoby młode o odpowiednich kwalifikacjach”, oraz że ,pomoc przeznaczana jest wyłącznie dla osób, które po raz pierwszy rozpoczynają samodzielne prowadzenie gospodarstwa rolnego" ${ }^{17}$.

Zaakcentowanie wskazanego wątku demograficznego wsparcia młodych rolników w logiczny sposób uzasadnia włączenie do celów poprawy konkurencyjności sektora rolnego i leśnego (Oś 1) także działania w zakresie wcześniejszych emerytur rolników ${ }^{18}$. Zestawienie tych dwóch sfer oddziaływania w dziedzinie realizacji celu poprawy konkurencyjności sektora rolnego i leśnego, jak również cytowane tu już zapisy o wspieraniu młodych rolników po raz pierwszy podejmujących działalność w gospodarstwach rolnych uzasadnia spojrzenie na problematykę sytuacji prawnej młodych rolników w ścisłym związku z regulacją prawną dotyczącą równoczesnego statusu prawnego starszych rolników. Dlatego też pozytywnie należy ocenić zabieg legislacyjny przyjęty w zmienionym w 2010 roku rozporządze-

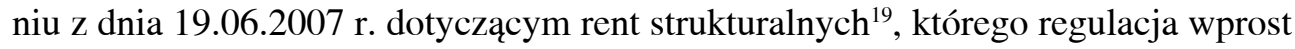
nawiązuje obecnie do przepisów określających sytuację prawną młodych rolników w związku z realizacją PROW ${ }^{20}$. Należy zauważyć, że rozporządzenie z dnia 19.06.2007 r. dotyczące rent strukturalnych w poprzednim swoim brzmieniu, sprzed cyt. wyżej nowelizacji z 2010 r., takiego bezpośredniego związku nie zawierało.

Rozp. Rady (WE) nr 1698/2005 z dnia 20.09.2005 r. w sprawie wsparcia rozwoju obszarów wiejskich przez Europejski Fundusz Rolny na rzecz Rozwoju Obszarów Wiejskich I EFRRO wl , Dz.U. UE L 277, 2005.

16 Załącznik do obwieszczenia Ministra Rolnictwa i Rozwoju Wsi z dnia 12.10.2007 r., M.P. Nr 94, poz. 1035 z późn. zm., cyt. dalej jako: PROW.

17 Pkt 5.3 PROW, s. 174.

18 Art. 20 pkt a lit.iii cyt.rozp. oraz art. 5 ust. 1 pkt 3 ustawy z dnia 7.03.2007 r. o wspieraniu rozwoju obszarów wiejskich z udziałem środków Europejskiego Funduszu Rolnego na rzecz Rozwoju Obszarów Wiejskich, Dz.U. Nr 64, poz. 427 ze zm.

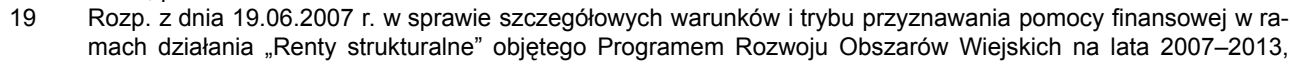
Dz.U. z 2010 r. Nr 131, poz. 886, cyt. dalej jako: „rozp, z dnia 19.06.2007 r.” w brzmieniu nadanym rozp. z dnia 16.07.2010 r., Dz.U. Nr 131, poz. 886.

20 Rozp. z dnia 17.10.2007 r. w sprawie szczegółowych warunków i trybu przyznawania pomocy finansowej w ramach działania „Ułatwianie startu młodym rolnikom” objętego Programem Rozwoju Obszarów Wiejskich na lata 2007-2013, Dz.U. Nr 200, poz.1443 z późn.zm., cyt. dalej jako „rozp, z dnia 17.10.200 r.” 
Wskazywana zmiana dotyczy wprawdzie tylko zastosowanego zabiegu legislacyjnego, ale z punktu widzenia założonych do realizacji celów dotyczących zmiany generacji $w$ rolnictwie jest to zmiana pozytywna. $\mathrm{W}$ ramach jednego aktu prawnego są zasygnalizowane jednocześnie trzy sfery oddziaływania na proces zmiany generacji w rolnictwie: 1) określenie sytuacji prawnej starszych rolników, 2) wskazanie na warunki, jakim mają odpowiadać młodzi rolnicy oraz 3) wyznaczenie celu przekształceń strukturalnych, a zwłaszcza poprawy struktury obszarowej gospodarstw rolnych. Rozporządzenie z dnia 19.06.2007 r. w sprawie rent strukturalnych zawiera wiele takich odesłań do rozporządzenia $\mathrm{z}$ dnia 17.10.2007 r. dotyczącego młodych rolników. Np. zgodnie z $§ 2$ pkt 3 pod pojęciem następcy rozumie się osobę fizyczną, która rozpoczyna prowadzenie działalności rolniczej po raz pierwszy $\mathrm{z}$ dniem przejęcia gospodarstwa rolnego od producenta rolnego ubiegającego się o rentę strukturalną, jeżeli do dnia wydania decyzji o przyznaniu renty strukturalnej temu producentowi rolnemu została tej osobie przyznana pomoc finansowa na podstawie rozporządzenia $\mathrm{z}$ dnia $17.10 .2007 \mathrm{r}$. W poprzednim brzmieniu rozporządzenia z dnia 19.06.2007 r. o rentach strukturalnych. Sprzed cyt. jego zmiany w $2010 \mathrm{r}$. odpowiedni przepis ( $\$ 2$ pkt 3) stanowił, że pod pojęciem następcy rozumie się osobę fizyczną, która rozpoczyna działalność rolniczą po raz pierwszy z dniem przejęcia gospodarstwa rolnego od producenta rolnego ubiegającego się o rentę strukturalną i nie ukończyła 40 roku życia w dniu złożenia wniosku o rentę strukturalną.

Takich bezpośrednich nawiązań w rozporządzeniu o rentach strukturalnych do przepisów rozporządzenia dotyczącego młodych rolników jest więcej. Nie cytując ich tu dokładnie, można poprzestać na wskazaniu np. na treści § 6 ust. 1 pkt 2 lit. a, czy $\S 7$ ust. 1 pkt 1 lit. b,e,f i g. Omawiana tu zmiana legislacyjna uzasadnia pytanie, czy te bezpośrednie odesłania w przepisach o rentach strukturalnych do przepisów odnoszących się do młodych rolników sprzyjać mogą przyspieszaniu, ułatwianiu startu młodym rolnikom w przejmowaniu gospodarstw rolnych w ramach instytucji rent strukturalnych, jakie są różnice w regulacji prawnej dotyczącej tej grupy rolników a innymi nabywcami gospodarstw w omawianym trybie. Uzasadniona będzie także próba oceny, w jakim zakresie przyjęte rozwiązania mogą służyć przemianom strukturalnym w rolnictwie, ale również próba odpowiedzi, czy zamierzone przekształcenia zachęcą młodych rolników do podejmowania przez nich prowadzenia gospodarstw rolnych. Poza zakresem niniejszych rozważań pozostaje w tym opracowaniu analiza sytuacji prawnej starszych rolników - beneficjentów pomocy finansowej w ramach instytucji rent strukturalnych. Problematyce tej poświęcono już w literaturze uwagę, wskazując zwłaszcza, że w rozwoju omawianej instytucji rent strukturalnych przyjmowane zmiany w większym stopniu prowadziły do poprawy struktury obszarowej gospodarstw rolnych oraz zaostrzały przesłanki nabycia świadczeń finansowych przez starszych rolników, przekazujących gospodarstwa rolne. Na tym tle trafnie odnotowano, że zasadniczym celem omawianych 
przepisów było dążenie do realizowania w większym niż dotychczas zakresie zmian strukturalnych w rolnictwie ${ }^{21}$.

5. Taki też kierunek wyznacza aktualnie obowiązująca regulacja prawna w przedmiocie przyznawania rent strukturalnych. Patrząc na sytuację prawną młodych rolników nabywających gospodarstwa rolne w omawianym trybie, należy zauważyć już na wstępie, że następuje ograniczenie kręgu potencjalnych nabywców spośród młodych rolników. Jak wynika z cytowanych już przepisów określających zakres pojęcia ,następca” rozporządzenia z 2004 roku oraz z 2007 roku, sprzed jego zmiany w 2010 roku, wystarczający był warunek nieukończenia przez następcę 40 roku życia w dniu złożenia wniosku o rentę strukturalną oraz rozpoczęcie działalności rolniczej po raz pierwszy. Natomiast według obecnego brzemienia $§ 2$ pkt 3 rozporządzenia z dnia 19.06.2007 r. następca musi spełnić, poza dotychczasowymi, także szereg innych, szczegółowo określonych warunków wymienionych w rozporządzeniu z dnia 17.10.2007 r. dotyczącego młodych rolników. Wśród tych warunków jest m.in. taki, który zakłada: nieprowadzenie działalności rolniczej w dniu złożenia wniosku o przyznanie pomocy i po raz pierwszy rozpoczęcie prowadzenia działalności rolniczej w gospodarstwie rolnym w rozumieniu art. 553 kodeksu cywilnego, jeżeli w wymaganym okresie:

- powierzchnia użytków rolnych w gospodarstwie będzie nie mniejsza niż średnia powierzchnia gruntów rolnych w gospodarstwie rolnym w kraju oraz nie większa niż 300 ha,

- gospodarstwo będzie prowadzone samodzielnie,

- budynki i budowle znajdujące się w gospodarstwie, wykorzystywane do produkcji rolnej oraz użytki rolne w gospodarstwie wykorzystywane do prowadzenia działalności rolniczej, nie będą stanowiły przedmiotu współwłasności lub współposiadania, z wyjątkiem małżeńskiej wspólności majątkowej,

- w gospodarstwie będą spełnione określone wymagania w zakresie ochrony środowiska, higieny i warunków utrzymania zwierząt.

Pierwszy z cytowanych tu warunków został częściowo zmodyfikowany przez treść wyrażoną w $§ 7$ ust.1 omawianego rozporządzenia z dnia 17.10.2007 r., zgodnie z którą dopuszcza się przyznanie pomocy osobie fizycznej, która przed dniem złożenia wniosku o przyznanie pomocy rozpoczęła prowadzenie działalności rolniczej w gospodarstwie rolnym, jeżeli od dnia rozpoczęcia prowadzenia działalności rolniczej do dnia złożenia wniosku o przyznanie pomocy nie upłynęło więcej niż

21 Por. E. Kremer, Zasady nabywania rent strukturalnych - zagadnienia wybrane, „Rejent” 2009, nr 3, s. 16 i 36 . Tak też P. Czechowski, Proces dostosowania polskiego prawa rolnego i żywnościowego do prawa Unii Europejskiej, Warszawa 2001, s. 148. 
12 miesięcy, a do dnia wydania decyzji o przyznaniu pomocy - więcej niż 18 miesięcy $^{22}$.

Zgodnie z treścią $§ 4$ ust.1 cyt. rozp. przez samodzielne prowadzenie gospodarstwa rozumie się prowadzenie gospodarstwa osobiście, na własny rachunek i we własnym imieniu, ponoszenie kosztów i czerpanie korzyści w związku z jego prowadzeniem. Natomiast $\S 4$ ust. 2 stanowi, że „uznaje się, że osoba fizyczna prowadzi gospodarstwo osobiście, jeżeli pracuje w tym gospodarstwie oraz podejmuje wszelkie decyzje dotyczące prowadzenia tego gospodarstwa".

Treść cytowanych tu przepisów, określających jeden z warunków uzasadniających przyznanie pomocy finansowej młodym rolnikom jednoznacznie wskazuje na powiązanie możliwości przyznania tej pomocy z dążeniem do realizacji celów strukturalnych i modernizacyjnych w rolnictwie. Równocześnie jednak może zastanawiać, dlaczego tak wyraźnie akcentuje się, że ta pomoc może być przyznana tylko tym, którzy po raz pierwszy rozpoczną prowadzenie działalności rolniczej. Takie unormowanie nie jest zgodne z wcześniejszymi postulatami literatury, by przejmowanie gospodarstw rolnych przez młodych rolników stanowiło raczej proces niż jednorazową czynność. R. Budzinowski pisał na ten temat m.in., że „regulacja ujmująca zmianę pokoleń jako proces zapewniłaby nie tylko „płynną” zmianę gospodarstwa, ale polepszałaby także sytuację starego rolnika. Mógłby on w szerszym zakresie, w miarę ubywania sił i pogarszania stanu zdrowia, dopuszczać następcę do prowadzenia gospodarstwa rolnego. Ten ostatni zaś miałby gwarancję otrzymania tego gospodarstwa z chwilą nabycia przez starego rolnika prawa do emerytury"23. Niektóre inne cytowane tu przepisy rozp. z dnia 17.10.2007 r. są z kolei pozytywną odpowiedzią ustawodawcy na zgłaszane wcześniej postulaty. Dotyczy to np. treści cyt. już $§ 4$ ust. 2, który określa, jak rozumie się na gruncie tego rozp. osobiste prowadzenie gospodarstwa rolnego przez osobę fizyczną. Wymaga się, by osoba ta nie tylko podejmowała wszelkie decyzje dotyczące prowadzenia gospodarstwa, ale także by pracowała w tym gospodarstwie ${ }^{24}$.

Zgodnie z treścią $§ 5$ ust. 4 za dzień rozpoczęcia prowadzenia działalności rolniczej przez młodego rolnika uznaje się dzień wejścia po raz pierwszy w posiadanie nieruchomości o powierzchni użytków rolnych co najmniej 1 ha. Na gruncie omawianego rozporządzenia wystarczająca jest więc przesłanka posiadania nieruchomości o określonej powierzchni użytków rolnych. Do uzyskania pomocy finansowej

$\S 7$ ust. 1 w brzmieniu rozp. z dnia 16.03.2011 r. zmieniającego rozp. w sprawie szczegółowych warunków i trybu przyznawania pomocy finansowej w ramach działania „Ułatwianie startu młodym rolnikom” objętego Programem Rozwoju Obszarów Wiejskich na lata 2007-2013, Dz.U. Nr 62, poz. 321.

Por. art. 6 ust. 2 ustawy z dnia 11.04.2003 r. o kształtowaniu ustroju rolnego, Dz.U. Nr 64, poz. 592 z późn. zm. oraz krytyczne uwagi na temat tego przepisu - A. Lichorowicz, Regulacja obrotu gruntami rolnymi według ustawy z 11. IV. 2003 r. o kształtowaniu ustroju rolnego na tle ustawodawstwa agrarnego Europy Zachodniej, „Studia luridica Agraria" 2005, t. 4, s. 25 oraz tenże, Instrumenty oddziaływania na strukturę gruntową Polski w ustawie z dnia 11 kwietnia 2003 r. o kształtowaniu ustroju rolnego, „Kwartalnik Prawa Prywatnego” 2004, z. 2, s. 400. 
według tego rozporządzenia nie jest wymagane prowadzenie tego gospodarstwa rolnego w oparciu o tytuł własności do nieruchomości.

Inaczej wygląda to na gruncie rozp. z dnia 19.06.2007 r. o rentach strukturalnych. Zgodnie z treścią $§ 6$ ust. 1 pkt 2 lit. a cyt. rozp. warunek przekazania gospodarstwa uważa się za spełniony, gdy przekazanie nastąpiło przez przeniesienie własności gospodarstwa rolnego w całości na rzecz następcy. Następca musi więc podjąć prowadzenie działalności rolniczej po przekazaniu mu gospodarstwa rolnego w trybie przepisów o rentach strukturalnych jako jego właściciel. Takie rozwiązanie zawęża możliwość nabywania gospodarstw rolnych w tym trybie i jest potwierdzeniem wcześniej zaznaczonej już tendencji, by zmierzać w kierunku trwałych, a nie czasowych zmian w strukturze obszarowej gospodarstw rolnych ${ }^{25}$.

Odnotowując inne warunki wskazane w rozporządzeniu z dnia 17.10.2007 r. dla młodych rolników i porównując je z sytuacją prawną tych rolników na gruncie rozporządzenia w sprawie rent strukturalnych, zauważamy z kolei łagodzenie warunków nabywania przez nich gospodarstw w trybie przepisów o rentach strukturalnych.

Dotyczy to np. warunku odnoszącego się do określenia wielkości nabywanego gospodarstwa rolnego przez młodego rolnika wskazanego w rozp. $\mathrm{z}$ dnia 17.10.2007 r. z odpowiednim przepisem rozp. z dnia 19.06.2007 r. w sprawie rent strukturalnych. W tym zakresie zauważamy podobne określenie wielkości przekazywanego gospodarstwa następcy, a ponadto korzystniejsze określenie dla następcy niż dla innych nabywców momentu spełnienia wskazanego warunku. Jak wynika bowiem z $\S 6$ ust. 1 pkt 2 lit. a rozp. o rentach strukturalnych, warunek przekazania gospodarstwa rolnego uważa się za spełniony, gdy przekazanie nastąpiło ,,przez przeniesienie własności gospodarstwa rolnego w całości na rzecz następcy, przy czym powierzchnia użytków rolnych wchodzących w skład gospodarstwa rolnego następcy po przekazaniu nie może być mniejsza niż średnia powierzchnia gruntów rolnych w gospodarstwie rolnym w kraju; w przypadku, gdy powierzchnia użytków rolnych wchodzących w skład gospodarstwa rolnego następcy po przekazaniu jest mniejsza niż średnia powierzchnia gruntów rolnych w kraju, następca powinien uzupełnić powierzchnię użytków rolnych w terminie określonym dla następcy na podstawie rozp. z dnia 17 października 2007 r." ${ }^{26}$ Takie rozwiązanie, przy braku odpowiedniego w przypadku przekazywania gospodarstwa rolnego innym nabywcom, jest przywilejem dla następcy. Jest zachętą do nabywania gospodarstw rolnych w tym trybie. od dnia doręczenia decyzji o przyznaniu pomocy i zachowany do dnia upływu 5 lat od dnia wypłaty pomocy $\S 5$ pkt. 1 i 2 cyt. rozp. 
Podobne preferencje zauważamy przy sposobie określenia warunku posiadania kwalifikacji zawodowych przez następcę. Należy na wstępie zauważyć, że w zakresie określenia kwalifikacji rolniczych w obu cytowanych tu rozp. nie ma w zasadzie - różnic. Potwierdza to zestawienie przepisów: $\S 6$ ust. 1 rozp. z dnia 17.10.2007 r. oraz $§ 7$ ust. 2 rozp. z dnia 19.06.2007 r. Różnica dotyczy tylko okreŚlenia stażu pracy w rolnictwie, co jest zrozumiałe zważywszy, że następcą nie może być osoba, która np. prowadziła działalność rolniczą w gospodarstwie rolnym ( 7 ust. 3 pkt 2 rozp. w sprawie rent strukturalnych). O ile zdefiniowanie kwalifikacji rolniczych w obu rozporządzeniach jest tożsame, to określenie momentu spełnienia tego warunku przez następcę w przepisach o rentach strukturalnych jest dla niego korzystniejsze niż dla innych nabywców. Zgodnie bowiem z treścią $§ 7$ ust. 1 pkt 1 pkt 1 lit. b, gdy gospodarstwo rolne jest przekazywane na rzecz następcy, który nie posiada odpowiednich kwalifikacji zawodowych w zakresie wykształcenia, warunek dotyczący posiadania tych kwalifikacji może być spełniony w terminie określonym dla następcy na podstawie rozp. z dnia 17 października 2007 r. Jest to, jak stanowi § 6 ust. 3 wskazanego rozporządzenia z dnia 17 października 2007 r., termin 3 lat od dnia doręczenia decyzji o przyznaniu pomocy.

Surowszy natomiast dla następcy, niewymagany od innych podmiotów przejmujących gospodarstwo rolne w trybie przepisów o rentach strukturalnych, jest warunek przedstawienia planu rozwoju przejmowanego gospodarstwa ( $\$ 2$ ust.1 pkt 3 rozp. $\mathrm{z}$ dnia 17.10.2007 r. i $\$ 7$ ust. 1 lit. g rozp. z dnia 19.06.2007 r.) Wspomniany warunek został wymieniony w przepisach o rentach strukturalnych po raz pierwszy w rozp. z dnia 19.06.2007 r. ${ }^{27}$ Wcześniej obowiązujące rozporządzenie w tej sprawie z dnia 30.04.2004 r. takiego warunku nie przewidywało. Wskazana zmiana potwierdza zwiększenie modernizacyjnych wymogów stawianych młodym nabywcom gospodarstw rolnych. W przyjmowanych rozwiązaniach prawnych podejmowana jest więc próba wspierania młodych rolników, by przyspieszać procesy demograficzne w rolnictwie, ale w powiązaniu z przekształceniami modernizacyjnymi - dla realizacji trwałych przekształceń strukturalnych $w$ rolnictwie.

Potwierdza to również szczegółowe uregulowanie dotyczące np. kolejności przyznawania młodym rolnikom pomocy finansowej według określonych kryteriów. Treść $§ 15$ cyt. rozporządzenia z dnia 18 października 2007 r. ${ }^{28}$ potwierdza, że liczba punktów przyznawanych młodym rolnikom, decydujących o kolejności przyznania pomocy, zależy np. od rodzaju posiadanego przez nich wykształcenia. I tak np. wnioskodawcy, który posiada wykształcenie wyższe rolnicze albo wykształcenie wyższe inne niż rolnicze i co najmniej 3-1etni staż pracy w rolnictwie, albo wykształcenie wyższe inne niż rolnicze i ukończone studia podyplomowe w zakresie 
związanym z rolnictwem - przyznaje się 5 punktów ( $\$ 15$ pkt 2 lit. a). Natomiast wnioskodawcy, który posiada wykształcenie średnie rolnicze albo wykształcenie średnie inne niż rolnicze i co najmniej 3-letni staż pracy w rolnictwie - przyznaje się 4 punkty ( $\$ 15$ pkt 2 lit. b). Dalsze postanowienia cyt. $\S 15$ wskazują odpowiednio na mniejszą ilość przyznawanych punktów w miarę obniżania się stopnia wykształcenia przez wnioskodawców. Cytowane rozwiązania dotyczące określenia kolejności przyznawania pomocy potwierdzają wsparcie procesu demograficznego w rolnictwie, ale równocześnie zwracają bardziej uwagę na potrzebę równoległego modernizowania rolnictwa. Osoby podejmujące prowadzenie gospodarstwa rolnego powinny posiadać odpowiednie przygotowanie zawodowe i w tym zakresie preferuje się tych, których stopień wykształcenia jest wyższy. Nie zawsze jednak to kryterium będzie decydujące. Odpowiednio preferowane rozwiązania są bowiem przyjmowane także bez względu na osobiste przymioty osoby nabywającej gospodarstwo rolne. Dotyczy to np. przyznawanej punktacji w tych województwach, gdzie występuje duże bezrobocie. Cyt. przepis $\S 15$ pkt 3 stanowi bowiem, że jeżeli bezrobocie w powiecie, na obszarze którego jest położone gospodarstwo wskazane w biznesplanie, było najwyższe w województwie - przyznaje się wnioskodawcy 5 punktów, natomiast gdy było niższe - przyznaje się proporcjonalnie mniej punktów do 0 punktów w przypadku, gdy bezrobocie w powiecie było najniższe w województwie. Demograficzny wydźwięk takiego rozwiązania jest jednoznaczny.

6. Lektura cytowanych tu szczegółowych regulacji określających przesłanki przyznania wsparcia finansowego młodym rolnikom pozwala zauważyć, że przy okazji udzielania tego wsparcia podejmuje się próbę jednoczesnego oddziaływania na różne cele przekształceń strukturalnych w rolnictwie.

Niewątpliwie kluczowym zagadnieniem jest przyspieszenie poprawy struktury obszarowej gospodarstw rolnych, dążenie do osiągnięcia trwałych skutków w tym zakresie, a więc przejmowanie gospodarstw rolnych przez młodych rolników na podstawie umów przeniesienia własności, ale równocześnie stawia się tej grupie rolników także określone warunki, które mają przyspieszać procesy modernizacyjne w rolnictwie. Zgodnie np. z treścią $§ 2$ ust. 1 lit. a rozp. z 17.10.2007 r. udzielenie pomocy finansowej uzależnione jest m.in. od spełnienia w gospodarstwie wymagań w zakresie ochrony środowiska, higieny i warunków utrzymania zwierząt.

Treść $\S 18$ ust. 1 pkt 3 tego rozp. wskazuje również, że beneficjent powinien realizować do dnia upływu 5 lat od dnia wypłaty pomocy założenia biznesplanu, a w szczególności np. prowadzić gospodarstwo zgodnie z określoną strukturą produkcji rolnej, czy wydatkować w okresie 3 lat od dnia wypłaty pomocy co najmniej $70 \%$ kwoty pomocy na inwestycje określone w biznesplanie.

Omawiana tu część regulacji prawnej dotyczącej wsparcia młodych rolników potwierdza wcześniej odnotowane już w literaturze spostrzeżenia bardziej ogól- 
ne, odnoszące się do oceny kryteriów wsparcia różnych beneficjentów Programu Rozwoju Obszarów Wiejskich, a mianowicie, że wspomniane regulacje zmierzają w kierunku rolnictwa ,mnogiego" 29 .

Generalnie można stwierdzić, że udzielanie pomocy finansowej młodym rolnikom jest wyrazem dążenia do przyspieszania procesów demograficznych na wsi. Potwierdza to także, w sensie formalnym, powiązanie tej części regulacji prawnej $\mathrm{z}$ przepisami dotyczącymi rent strukturalnych $\mathrm{w}$ rolnictwie ${ }^{30}$. Równocześnie jednak stawia się tym rolnikom obowiązek spełnienia całego szeregu warunków, które nawiązują już nie tyle do samego podmiotu podejmującego prowadzenie gospodarstwa rolnego, ile do różnych celów polityki rolnej. Sytuacja prawna młodego rolnika $\mathrm{w}$ procesie zmiany generacji $\mathrm{w}$ rolnictwie jest określana mniej lub bardziej rygorystycznie niż innego podmiotu nabywającego w tym trybie gospodarstwo rolne. Ma on, o czym już była mowa, pewne preferencje przyznane w przepisach o rentach strukturalnych (np. w zakresie czasu spełnienia warunku kwalifikacji, czy wielkości nabywanego gospodarstwa rolnego), ale inne $\mathrm{z}$ kolei warunki są związane $\mathrm{z}$ większymi rygorami. Np. nabywca niebędący młodym rolnikiem (następcą) według § 7 ust. 1 pkt 1 lit. d rozp. o rentach strukturalnych powinien zobowiązać się do prowadzenia osobiście działalności rolniczej na przejętych użytkach rolnych przez okres co najmniej 5 lat. Jak zauważyła E. Kremer, wprowadzenie tego wymogu nie zostało powiązane z żadnymi negatywnymi konsekwencjami w przypadku jego zaniechania. ${ }^{31}$

Natomiast gdy nabywcą jest młody rolnik, obowiązek 5-letniego okresu prowadzenia gospodarstwa jest zaostrzony wymogiem realizacji w tym okresie założeń biznesplanu (§ 18 ust. 1 pkt 1), obowiązkiem umożliwienia przeprowadzenia kontroli przez uprawnione podmioty oraz możliwością zastosowania sankcji w postaci zwrotu kwot udzielonej pomocy ( $\$ 20$ ust. 1, 3 i 4 cyt. rozp.). Wskazane rozwiązanie jest zrozumiałe, zważywszy zwłaszcza że w przeszłości dochodziło w tym zakresie do wielu nadużyć, do np. pozornego przekazywania gospodarstw młodym rolnikom ${ }^{32}$.

Równocześnie należy zauważyć, że zróżnicowana zostaje skuteczność realizacji określonych celów na gruncie przepisów o rentach strukturalnych. W przypadku innych niż młodzi rolnicy nabywców gospodarstw rolnych wystarczające jest, jak już była o tym mowa, zobowiązanie prowadzenia działalności rolniczej przez okres co najmniej 5 lat - bez kontroli spełnienia tego warunku, bez konieczności przedstawiania biznesplanu. W tym przypadku można więc tylko mówić o dążeniu do

Tak P. Blajer, Beneficjenci „Programu Rozwoju Obszarów Wiejskich”, „Przegląd Prawa Rolnego” 2010, nr 1, s. 32.

30 Por. P. Blajer, Zmiana generacji w gospodarstwach rolnych w Polsce w świetle polityki rozwoju obszarów wiejskich (aspekty prawne), „Przegląd Prawa Rolnego” 2010, nr 2, s. 172 i n. ki strukturalnej, „Studia luridica Agraria” 2009, t. 7, s. 206 oraz P. Blajer, Zmiana generacji..., op. cit., s. 172. 
realizacji, w umiarkowanym stopniu, celu demograficznego. Innym rolnikiem niż następca może być bowiem rolnik, który nie ukończył 50 roku życia. Natomiast w takim przypadku nie możemy mówić o skuteczności realizacji celu modernizacyjnego. Większy stopień skuteczności osiągania zamierzonych celów wiąże się natomiast z przyjmowanymi regulacjami dotyczącymi młodych rolników jako nabywców gospodarstw rolnych, dla których wymagania są dalej idące.

W ramach jednej instytucji prawnej, jaką są renty strukturalne, jednolicie określa się więc cele polityki rolnej: dążenie do harmonizacji zmiany generacji w rolnictwie, poprawę struktury obszarowej gospodarstw rolnych, modernizację gospodarstw, ale środki prawne dla ich realizacji są zróżnicowane ze względu na podmiot, który w tym trybie podejmuje prowadzenie gospodarstwa rolnego. Szczególne oczekiwania wiązane są z młodymi rolnikami, których sytuacja prawna jest jednak bardziej rygorystycznie określana niż innych nabywców. Powstaje pytanie, czy oferowane im wsparcie finansowe będzie dostateczną zachętą do podejmowania wysiłku spełnienia stawianych im warunków. Przy założeniu oczywiście, że dla starszych rolników, beneficjentów pomocy w ramach instytucji rent strukturalnych, przekazywanie gospodarstw rolnych w tym trybie będzie także atrakcyjną formą zmiany generacji. Poszukiwanie bardziej wyważonych ocen wymagałoby pogłębionej, całościowej analizy regulacji prawnej w tym względzie. 


\section{Legal situation of young farmers in the process of generation change in agriculture}

Key words: young farmer, structural pension, agricultural holding

The subject of this essay is the legal situation of young farmers in the process of generations change in agriculture. This issue is particularly current in relation to the process of reconstruction of the agricultural structure. It is reasonable to consider the legal situation of young farmers in connection with the legal regulation concerning the legal status of older farmers, especially the regulation on structural pensions in agriculture. Essay attempts to answer whether the regulations may favor acceleration, facilitation of young farmers taking over farms. The answer is ambiguous. On one hand, the conditions to be met by young farmers are defined for them more liberal than for other grantees but on the other hand these conditions are defined more rigorously. Conditions indicated for young farmers - grantees of agricultural holdings - are determined especially by the agricultural policy objectives, particularly its demographic purpose, purpose of modernization, and above all purpose of improving territorial structure of farms. Existing solutions in this area are an expression of legislative efforts to achieve long-term effects of structural changes in agriculture. 